\title{
Participatory Assessment of Ecosystem Services from Community-Managed Planted Forests in Bhutan
}

\author{
Prem Bahadur Rai ${ }^{1}$, Robin R. Sears ${ }^{2,3}$, Dorji Dukpa ${ }^{1}$, Sonam Phuntsho ${ }^{4}$, Yustina Artati ${ }^{3, *}$ \\ and Himlal Baral ${ }^{3,5}$ (D) \\ 1 Ugyen Wangchuck Institute for Conservation and Environmental Research (UWICER), \\ Post Box 155 Bumthang, Bhutan; pbrai@uwice.gov.bt (P.B.R.); ddukpa@uwice.gov.bt (D.D.) \\ 2 Williams College, Williamstown, MA 01267, USA; robin.sears@aya.yale.edu \\ 3 Center for International Forestry Research (CIFOR), Jalan CIFOR, Situ Gede, Bogor 16115, Indonesia; \\ h.baral@cgiar.org \\ 4 The School for Field Studies (SFS), Post Box 1308 Paro, Bhutan; sphuntsho@fieldstudies.org \\ 5 School of Ecosystem and Forest Sciences, University of Melbourne, Parkville, VIC 3010, Australia \\ * Correspondence: y.artati@cgiar.org
}

Received: 13 July 2020; Accepted: 23 September 2020; Published: 30 September 2020

\begin{abstract}
Planted forests provide a range of ecosystem services, from the local to global scales. In this study, we evaluated the perceptions by local people of the ecosystem services from planted forest stands in Bhutan. We employed household questionnaires, interviews and focus group discussions in eight villages in two regions of Bhutan: Trashigang dzongkhag, in eastern Bhutan, and Punakha dzongkhag in western Bhutan. At all sites, the planted forests were created several decades ago to restore forest cover in deforested and degraded areas. The restored stands were perceived by residents to provide multiple goods and ecosystem services important to local security, health, and livelihoods, including wild edibles, freshwater, and soil protection, and aesthetic and cultural services. This study indicates that local community participation in forest resource management can ease user conflict and manage the planted forests sustainably. We see community-based forest restoration on degraded lands as a viable approach, among others, to achieve national commitments to the Bonn Challenge and other multilateral environmental agreements related to forests.
\end{abstract}

Keywords: planted forest; community forest; ecosystem services; forest restoration; degraded land; Bhutan

\section{Introduction}

Globally, natural forest area is decreasing and planted forest area is increasing, the latter accounting for $7 \%$ of the total global forest area [1]. This figure reflects the amount of forest under the broad definition of planted forest: "forest predominantly composed of trees established through planting and/or deliberate seedling" [2]. Despite the main purpose being to produce timber, planted forest can provide a broader set of social and environmental benefits [3] and assist in the restoration of degraded land to generate improvement of livelihoods and environmental outcomes [4]. Planted forest also can improve ecosystem services and enhance biodiversity conservation, although the structure and composition may not be the same as the original forest cover [5]. Local communities play an important role in the restoration of degraded land, including in providing critical local knowledge and stewardship; they are motivated to participate in restoration especially if selected tree species have both ecological and economic values, and if the restoration is in line with local development priorities [6].

While large-scale planted forests are increasing globally, and they are well studied, small-scale community-based plantations are not well represented in the literature. The economic and 
environmental outcomes of these small planted forests are largely unknown. In highly forested countries such as Bhutan, in areas of forest and land degradation, the government has relied on the participation of local communities for restoration. The outcomes of such community forest restoration projects have yet to be systematically explored. This present study was designed to help to fill that gap.

\subsection{The Roles and Values of Planted Forests}

Claims and counterclaims on the role of planted forests in restoration of degraded lands, biodiversity conservation and climate change mitigation are many. There is no doubt that intensive industrial plantation forestry is critical to meet global wood demand, and up to 90 percent of demand is met this way in some countries [7]. It is well recognized, however, that monoculture timber plantations harbor only low levels of biodiversity [8,9], and the claim that commercial timber plantations will contribute to climate change mitigation through carbon sequestration is challenged [10].

Forest establishment for protection, or for multiple benefits, is less controversial than restoration for production and is recognized as an essential approach to conservation, coupled with protection of intact forests [5]. Planted forests that are diverse in composition and structure, on the other hand, and that fulfill a variety of objectives [7] can play an important role in biodiversity conservation and ecosystem restoration $[11,12]$.

The social values, both positive and negative, of planted forests are less well explored $[13,14]$. The establishment of forest plantations can provide desirable local employment or leasing arrangements and rural development initiatives by the company, but it can bring negative social and environmental impacts. For example, the introduction of a pulp industry and associated plantations of exotic trees in Uruguay has adversely affected the ranchers and farmers living on the land, with drying water wells, loss of productive land and social isolation [15]. In Indonesia, the establishment of large-scale plantations has resulted in loss of access to productive land by local farmers [13]. Widespread forest restoration in China has had mixed impacts, from increased soil protection and reduction in local flood risk to diminishing food security and increasing social inequality [16].

Besides providing goods, such as timber, fuelwood and non-wood forest products, planted forests can also provide environmental and social services, ranging from rehabilitation of degraded soil, watershed protection, carbon sequestration, recreation and landscape amenities. The suite of ecosystem services derived from planted forests depends on many factors, including kinds and numbers of species planted, objectives of the planting, and site conditions [17]. Comparing the ecosystem services from intensively managed planted forests to native forests, Baral and colleagues [17] found that the former provided relatively higher services in only two areas-timber production and carbon sequestration-while all other provisioning, regulating, supporting and cultural services were relatively poorer in the planted forest. On the other hand, more of the services from planted forests with mixed species composition, complex structure and less management may be on a par with those from natural forest. The main trade-off between these "semi-natural" forests and monoculture plantations are in ecological services, and the social and cultural values of these, versus provisioning services of timber production.

\subsection{Degraded Land Restoration Using Planted Forest: Policy Imperative}

Afforestation and reforestation of degraded lands is a focus point for governments and communities alike around the world [18] as a strategy to restore the safety and security of local residents and to improve biodiversity in all of its dimensions [19]. Degraded land commonly refers to 'land with low agricultural productivity and capability because of infertility, erosion, weeds or recurrent fires' [4]. However, the category depends on biophysical constraints, current use, location, and the institutional policy settings that apply to it. Increasing land degradation may lead to more land competition for food production, and the consequent conversion of natural forest to agricultural land, which ultimately results in a loss of forest functions in providing ecosystem services, such as soil and water protection, climate regulation, and habitat to maintain biodiversity $[20,21]$. On the other hand, degraded lands 
have more likely been abandoned and, thus, have more potential for reforestation compared to marginal and fragile lands [4]. Countries in mountain regions especially can benefit from forest restoration on degraded hillsides because those forests play a significant role in providing services to downstream areas [21-24]. In addition, remote uplands tend to have low agricultural productivity, which will reduce the opportunity cost of restoring it to forest [4]. Governments in mountain regions have been revisiting and reorienting their forest policies and are moving their attention from a focus on timber extraction toward a multipurpose approach involving conservation, restoration and production $[23,25]$. This shift is a recognition that the suite of ecosystem services from intact and restored forests are vital for local livelihoods as well as critical for ecosystem function, especially in rural settings.

Located in the eastern Himalaya, Bhutan is one such mountainous country whose forest policy has shifted in recent years to embrace conservation, protection and restoration through decentralization and devolution to local communities. It has done so in response to poor outcomes of older forest policies. For example, the nationalization of all forest management responsibilities in 1969 led to the exclusion of local communities of their traditional rights to forest resources [26]. The communities thus had little autonomy to control and benefit from the forests, and low motivation to contribute to their management. With the passage of time, the government realized that sustainable management of forests could be achieved only through the participation of local communities; hence, the management of forest resources was adopted with the participation of local communities [27].

The 2017 forest and nature conservation policy in Bhutan [28] treats plantation forests in a variety of ways, depending on the nature and purpose of the plantation. Planted forests are considered in sections related to afforestation, reforestation, community plantation and others. In general, however, the policy states that planting trees is mandatory in areas devoid of vegetation due to natural regeneration failure, and any vegetation lost while establishing development projects need to be compensated with forest plantation. It also highlights the participation of communities in planted forest initiatives, including in the rehabilitation of degraded or bare lands for improvement through community forestry. The policy and other associated policies and regulations encourage private actors and communities to plan on their own and state lands to reduce pressure on natural forests for timber production and to mitigate forest loss from forest fire and shifting cultivation [29].

Community-based forest management in Bhutan started to be institutionalized in the late 1990s [30], and the community forest areas may include degraded forest or deforested areas as well as intact natural forests. It has shown progressive success indicated by the numbers and total area of community forests, and number of participating households. By 2018 there were 781 designated community forests covering an area of over than 92 thousand hectares and with over 32 thousand households formally involved [31]. It is shown that participation in community forestry has had positive impacts on household income and food security [27,32,33].

Bhutan's government has for a long-time prioritized reforestation to maintain the integrity of the country's mountainous landscapes. Plantation programs were initiated by civil authorities in the 1940s, even before the establishment of the Department of Forests (DoF) in 1952 [34] and the government encouraged people to carry out forest restoration activities in barren and degraded lands near the rural settlements. The areas of planted forests for restoration were called "community plantations" and were initiated to address problems related to forest degradation together with the aim to meet the basic forest product needs of the community for fuelwood, timber, and fodder for livestock in a sustainable manner. Since then, and following a 1997 royal decree from the Fourth King, which commanded the involvement of local people in tree planting activities $[29,35]$, the DoF had been facilitating communities to carry out systematic tree planting initiatives, with over 17,400 ha established by 2015 . Planted forests are appearing also on private lands with the primary objective of wood production, but these private plantations account for less than 12 hectares in total [31].

The direct benefits from community forests have been assessed in case studies in Bhutan $[30,33,36]$. Only a few case studies on ecosystem services derived from natural forests have been documented in Bhutan $[37,38]$. The community plantations that were established prior to the formal establishment 
of the community forest category were formally licensed to qualify as community forest, with the inclusion of additional government reserve forest areas. Today, many of these planted areas are more than two decades old, and it is worthwhile to assess the social dynamics of their establishment and maintenance and their contributions to the livelihoods of local participant.

The concept of planted forests beyond timber production has gained momentum in the country, and, in this context, the aim of this paper is to report on how the Bhutanese people perceive the values of planted forests in terms of ecosystem services that contribute to their well-being and to the local environment. Specifically, we focused on two questions. First, we asked how participating community members view the outcomes of the community plantation initiatives in the 1990s, and have the original objectives of the initiative been met. Second, we asked community residents to identify and rank the ecosystem goods and services that they perceive originate in the community plantation areas.

\section{Materials and Methods}

\subsection{Study Areas}

Bhutan is located in eastern Himalaya and is a mountainous country, with elevations ranging from $200 \mathrm{~m}$ above mean sea level (AMSL) in the south to $7000+\mathrm{m}$ in the north. The vegetation zones start with subtropical broadleaf forest in the southern foothills, through warm then cool temperate broadleaf, to conifer forests with increase in elevation and changes in precipitation [39]. The study was conducted in two districts (dzongkhags) in Bhutan-Punakha and Trashigang-located in western and eastern Bhutan, respectively (Figure 1). These districts were selected because they were the first to establish community plantations (Table 1) in the early 1990s.

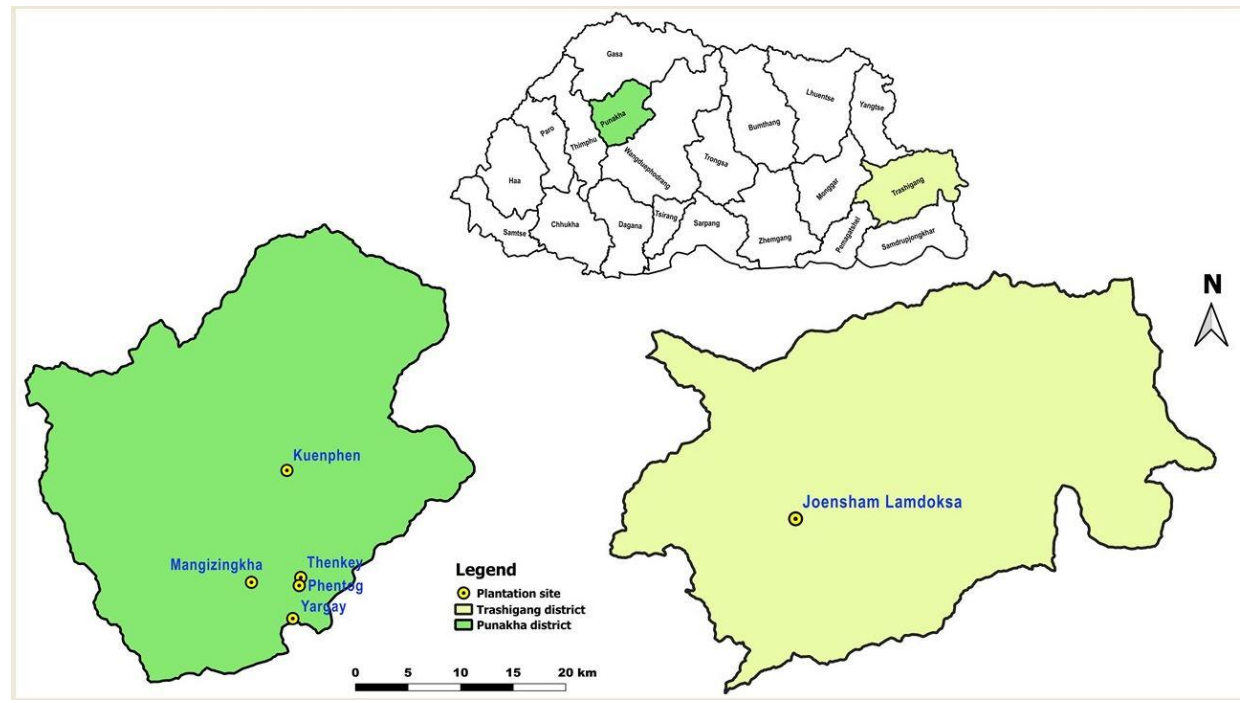

Figure 1. Location of the planted forests studied in Punakha (green) and Trashigang (yellow) dzongkhags, Bhutan. (Map created Jigme Wangchuk, 2019).

\subsubsection{Site 1: Punakha Dzongkhag}

Punakha is located in western Bhutan and has a varied topography and climate. The majority of the district lies between 1200 and $3600 \mathrm{~m}$ AMSL, and annual rainfall ranges from 500 to $1500 \mathrm{~mm}$. The rural people practice subsistence farming and rely on forest resources. Forest cover was 84 percent in 2016, dominated by broadleaf, mixed conifer, chir pine and fir [40]. The planted forests were initiated in the early 1990s with support from international funding, with exotic Cupressus sp. (cypress) targeted for its fast growth and timber quality. All five planted forests under study (Table 1) were formally licensed (regularized) into greater community forests between 2005 and 2007, which gave the community forest management group (CFMG) members more incentive to engage. According to the 
management plans for these community forests, the main objective for the planting was to recuperate deforested and degraded land with forest cover, with a secondary objective to produce wood products.

Table 1. Community plantations in selected areas with district location, area, number of households in the Community Forest Management Group (CFMG) and year planting initiated.

\begin{tabular}{ccccc}
\hline $\begin{array}{c}\text { Name of Community } \\
\text { Plantation }\end{array}$ & Dzongkhag & Area (ha) & $\begin{array}{c}\text { No. of Households in } \\
\text { CFMG }\end{array}$ & Year Initiated \\
\hline Mangizingkha & Punakha & 1.0 & 17 & $1991-1992$ \\
Yargey & Punakha & 15.0 & 20 & $1993-1994$ \\
Kuenphen & Punakha & 1.0 & 42 & 1993 \\
Thuenkey & Punakha & 0.9 & 24 & 1993 \\
Phentog & Punakha & 1.4 & 28 & 1993 \\
Joensham Lomdoksa & Trashigang & 4.1 & 174 & 2001 \\
\hline
\end{tabular}

Source: Wangdue Divisional Forest Office [41].

\subsubsection{Site 2: Trashigang Dzongkhag}

Trashingang dzongkhag is located in the far east of the country, in an arid zone. The district lies between 500-4500 m AMSLand the annual precipitation is between 1000 and $2000 \mathrm{~mm}$. The dzongkhag forest cover is dominated by broadleaf forests and some chir pine, mixed conifers and fir [40].

The study was conducted in Joensham Lomdoksa Community Forest (Table 1) in Khaling geog (sub-district), which occupies 558 ha in four non-contiguous nearby blocks. There are 31 ha of planted forest in the community forest (CF), and we focus on one 4 ha block (Figure 2). Three villages associated with the planted forest area are Rashong, Dawzor, and Bremeng-Dangrey-Kholdong, comprising 174 households. The plantation is located on a very steep slope with a southern aspect and elevation of 2550 to $2260 \mathrm{~m}$ AMSL. Midway down the slope, a shallow dry creek emerges and ends at the base of the ridge.

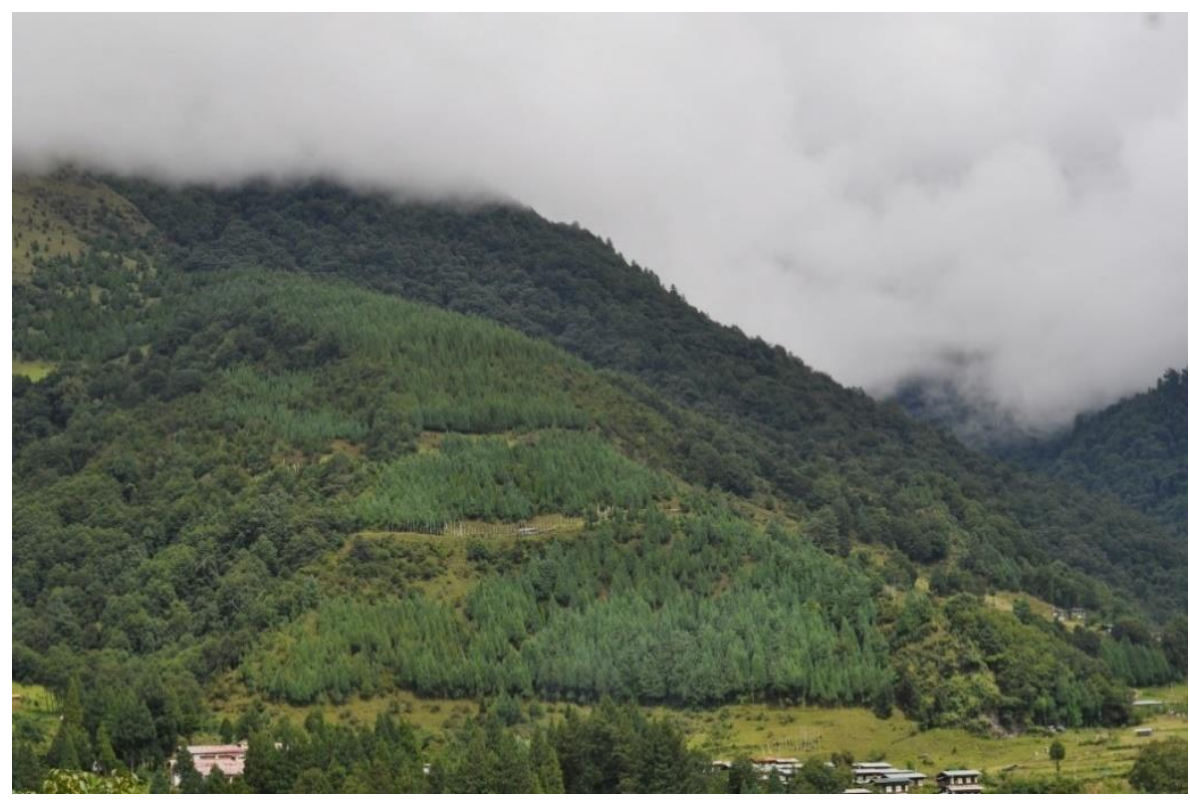

Figure 2. Community plantations in Trashigang dzongkhag, Eastern Bhutan.

Although the vegetation in the larger community forest is cool broadleaf forest, an exotic cypress was selected for the restoration planting on the degraded sites because it has fast growth, valuable, and sacred timber. Systematic tree planting at this site was initiated in 2001 and continued every two years until 2007, with the objectives to restore degraded land, control soil erosion, protect water 
catchment areas and to later utilize the wood resources. By 2017, at the time of this study, the ages of the trees in the plantation were 10 to 16 years, a range that was confirmed by analyzing tree cores from 20 randomly selected trees in the planted area.

\subsubsection{The Planted Forests}

The species planted in all areas was an unknown exotic species of Cupressus sp. (cypress), selected for its fast growth and softwood quality, good for house construction and furniture. Some Cryptomeria sp. (cryptomeria) was planted later. The areas of planted forest under community forest management assessed in this study across the two sites were mostly very small (Table 1), with a mean and standard deviation of $3.9 \pm 5.6 \mathrm{ha}$, and a median of $1.2 \mathrm{ha}$. Details on each of the forests are presented here to show the conditions of establishment and management, and outcomes.

Mangizingkha CF, Punakha, contains 1 ha of planted forest, which was originally planted on private land but then handed over to the community for restoration to meet timber requirements of the local population. The plantation, mainly cypress and later cryptomeria, was regularized as community forest in 2005 together with a portion of the nearby government reserve forest (GRF). Every year, community members gather to prune the trees and remove the competing vegetation.

Kuenphen CF, Punakha, contains 1 ha of planted forest on a gentle slope with cypress and later a few cryptomeria. Management involves occasional brush cutting and "social fencing", whereby community members take turns on watch for intruders. One thinning was carried out in 2008 to remove diseased and malformed trees and it is in need of a second round.

Thuenkey CF, Punakha, contains 0.9 ha of planted forest established in 1993 with cypress. The area has yet to be incorporated into the current community forest management plan, although the CFMG still manages it. There was no evidence of any tree removal or thinning operations from the planted area.

Yargey CF, Punakha, contains 15 ha of planted forest of cypress and is located on a steep slope with a southerly aspect and extremely dry soil. Later, Quercus griffithii (oak) was intermixed, today comprising five percent of the total number of trees. The planted area expands every year, mostly with additional cypress. The CFMG members have carried out pruning of cypress trees to sell residue to a local incense factory.

Phentog CF, Punakha, plantation of 1.4 ha was established on barren land in 1993, primarily with cypress, and was recognized then as the best plantation in the region. The plantation was duly incorporated and included in the community forest in 2007, but it was destroyed by forest fire in the same year. The Phentog CFMG members replanted soon after the fire incident, but the trees failed to establish. The land was taken over by Druk Holding Investment in 2014 to make way for the construction of a wilderness resort, and the community no longer has control of the planted forest area.

Joensham Lomdoksa CF, Trashigang, the planted forest was established between 2001 and 2007 with a total area of 4 ha and planted mainly with cypress. The plantation was established on a grassy slope that served as a winter grazing area for nomadic and local herders prior to restoration. The degraded area planted out bisected otherwise intact high forest stands, and thus the present planted forest has created a corridor that connects the high forest on either side of the plantation. No thinning operations had been conducted in the stand since planting.

\subsection{Survey Design}

We applied social surveys in 2017 to generate information from CFMG members about the benefits and costs of the planted forests, and to identify and prioritize the ecosystem services from their planted forest areas. We worked in the 8 villages associated with the community plantations in the two study areas using household questionnaires and interviews, focus group discussions, and key informant interviews.

We centered the interviews and discussions on three main questions: What types of ecosystem services are being provided by the planted forest? How do CFMG members perceive the value of their planted forest area? What is the potential for future ecosystem services from the planted forests? 
The livelihood of the households in all three communities was mainly based on subsistence farming and livestock herding, and as such, are connected to the forest.

While the main objectives of our study were the same in the two study areas, they were achieved through slightly different methods. The specific methods employed at each site were adopted based on the recommendation of the local forest officers and local community leaders, who made the recommendations to optimize our access to CFMG members while minimizing disruption to their livelihood work. In Punakha, we conducted semi-structured interviews with CFMG members, who came from the eight villages associated with the five planted forest areas (some CFMGs have members from several villages). In Trashigang, we conducted a focus group discussion in each of the three villages associated with the single community plantation (Figure 3). We believe that these two methods generated information that was similar enough in nature and depth to allow for valid comparisons across the sites. The study area and research protocols for the two study sites are herewith described separately.

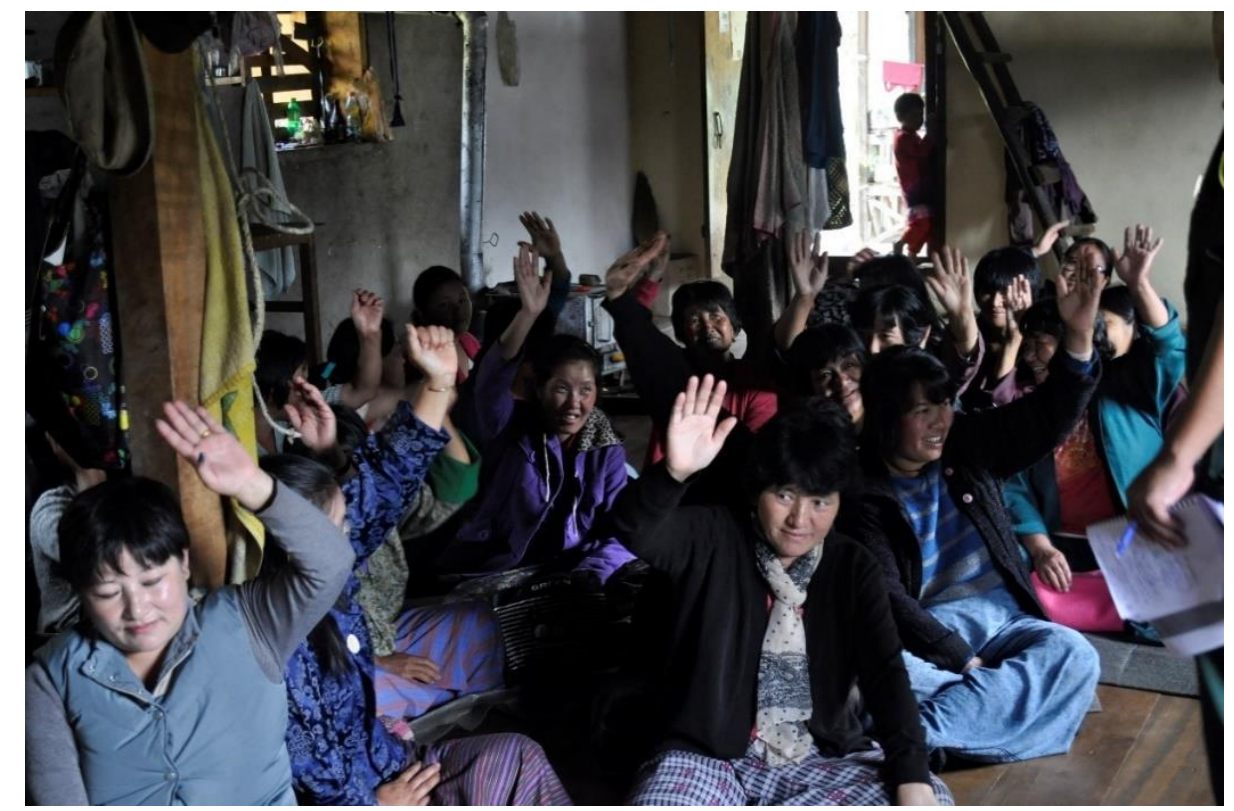

Figure 3. Female participants in one of the focus group discussion at Trashigang dzongkhag.

The social survey in Punakha was based on semi-structured interviews in CFMG member households associated with the planted forest area. In total, CFMG members from 94 households (of 131 total CFMG members) were interviewed; 49 were heads and the rest were members of the household. Sixty-three percent of the interviewees were female. Households were selected based on their availability on the day of the survey. The interviewees represented diverse age groups from 16 to 83 years old, and the majority (52 percent) were aged between 41 to 60 years, an age class whose members play essential roles in decision making and management of the community forest. To complement the information from householders, we consulted with district forest officers and reviewed records and materials of the plantations maintained by CFMGs or relevant offices.

In Trashigang, we identified the three villages associated with the planted forest area. These were the communities of Rashong, Dawzor, and Bremeng-Dangrey-Kholdong, and were involved from the beginning of the restoration initiative in 2001 and recently are the only villages that have the access right to this planted forest. The three villages area located within one kilometer down slope (south to south-west) of the planted forest area, with Rashong and Dawzor being the closest. The livelihood of the households in all three communities was mainly based on subsistence farming and livestock herding.

In total, 118 members of the 174 permanent households of the three villages participated in the three discussions. They consisted of 33, 49 and 33 participants from Rashong, Dawzor, 
and Bremeng-Dangrey-Kholdong, respectively. Sixty percent of the participants were women, who also tended to be more vocal than men during the discussion. Local forest officers served to assist in facilitating and translating the terminology of ecosystem services into the local dialect.

The focus group sessions began with a general orientation to the concept of ecosystem services. While none of the participants had heard the term "ecosystem services" prior to our discussion, when they were oriented to a few key services, such as water regulation and aesthetic value, they quickly understood the meaning and the value. The orientation was followed by questions and group discussion to identify the key ecosystem services from the planted forests and the trends in their availability. A decision on the trends for each service was reached by raising their hands, and agreement on certain issues was considered when a majority of the hands were up. In our study, preference points were used for prioritization of the services identified (first, second, third, fourth, fifth and sixth).

\subsection{Ecosystem Services Framework and Data Analysis}

While planted forests can provide a wide range of ecosystem goods and services, the number of and magnitude of services vary depending on the forest's position on the landscape, area of the plantation, choice of species and associated management practices. A framework for conducting a qualitative assessment of ecosystem services from planted forests proposed by Baral et al. [17] was used to identify and assess ecosystem services from community planted forests in this study. This framework has been applied and tested in various types of planted forests in the region, such as in bamboo forests [42] and planted forests in Vietnam [43].

The central unit of analysis in this study is the planted forest, and we conduct a qualitative analysis on the data from household interviews and focus group discussions with community forest management group (CFMG) members. We coded answers and quantified and ranked when possible. Each planted forest is overseen by a single CFMG, which might consist of one or several villages. We were looking at perceptions both within and between the CFMGs. In the case of Trashigang, where the CFMG comprised members of three villages with different geographical positions to the forest, we were particularly interested in the similarities and differences among the villages (within the CFMG). In the case of Punakha, we were looking for the same, but among different CFMGs.

\section{Results}

In general, participants in all the study villages at both sites identified two main initial management objectives for the plantations: first to meet future demand of timber and firewood, and second to prevent uncontrolled soil erosion and further land degradation.

\subsection{Meeting Community Objectives}

In Punakha, the primary objectives for revegetating these areas mentioned by villagers were to meet future demand for wood (56 percent of respondents), protect the soil (38 percent), improve aesthetic value of the site ( 3 percent) and protect a water source ( 2 percent). Nearly all respondents in all communities but Phuentog felt that objectives had been met. They were highly or moderately satisfied about the outcome of their efforts to restore the forest due to the good growth of trees (Figure 4). Although the plantations currently do not provide timber, the CFMG members have high expectations for meeting future wood needs, feeling that the growth of the trees is promising.

While a majority of the participants had worked in the plantation originally (85 percent), few still do (35 percent). Those who do reported entering annually or periodically to clear understory brush, prune trees, carry out enrichment planting, or to plant additional area. They also enter the stands to patrol for illegal activity as a type of "social fencing."

Respondents in Punakha identified various issues and constraints to effective management. Labor intensity in the initial establishment and later management of the plantations was mentioned in two communities. The low survivorship of recently planted saplings was cited by two groups, due to poor soil quality, lack of direct watering or nearby water source and grazing by cattle. The low soil 
quality at Yargey resulted in poor tree growth, showing an average DBH of $12 \mathrm{~cm}$ compared to $20 \mathrm{~cm}$ in Kuenphen for cypress trees initiated the same year. Uncontrolled fire from rice paddy clearing was cited by one group as a threat to the planted forest. One group mentioned that disturbance from outsiders was a threat and stressed the need to patrol the site.

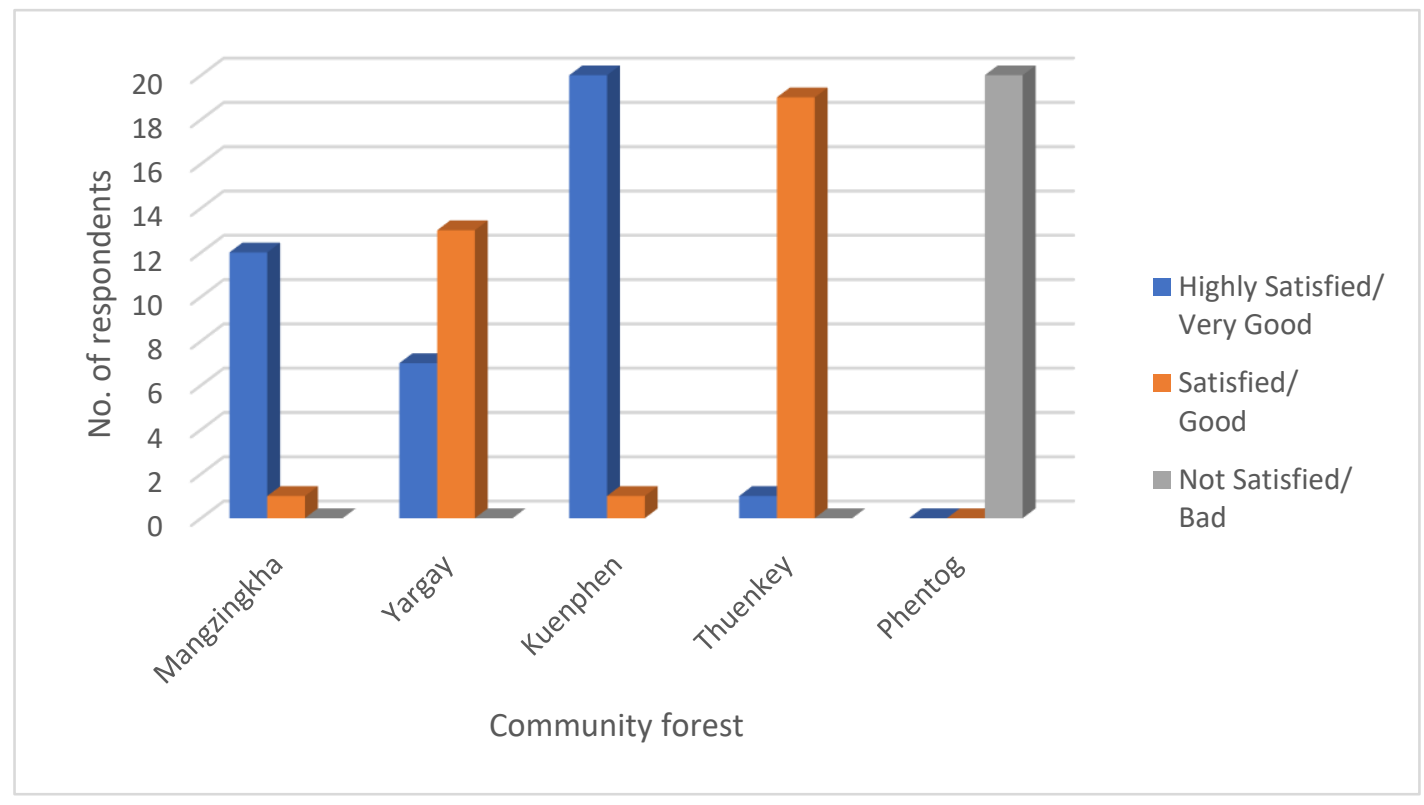

Figure 4. Level of satisfaction of the community forest management group (CFMG) members about their plantations in five villages in Punakha dzongkhag.

The planted forest area in most villages was never fenced, rather being protected by social fencing, in which community members keep a watch. Wildlife damage to trees was mentioned by members at one site only, despite being the only plantation that had been fenced initially. They informed that barking deer, sambar deer, and wild pigs were debarking and uprooting saplings. At the same time, new appearance of wildlife in the forested area was cited by three villages in Punakha. Wildlife was also noted to disappear, as in one village, several people said that they used to see birds, including junglefowl (Gallus gallus), in the bushes prior to the plantation, and now they do not see them.

In Khaling, Trashigang, we observed, as the foresters suggested, that stand development is becoming stagnant, revealed by the absence of seedlings and saplings in the understory. Community members corroborated this, suggesting that the stands would respond well to a thinning operation, particularly to achieve the eventual goal of timber production.

Some of the issues mentioned above could be resolved with intervention or improvement, according to respondents. Fencing around the perimeter of the plantation could reduce damage by wild animals and grazing cattle. Grazing damage could be reduced also through improving cooperation among CFMG members and by strengthening by-laws in the CF management plans. Community development and cooperation could be achieved through repeated awareness raising and empowerment workshops, respectively. The construction of fire lines around the plantations could be encouraged to reduce the fire hazards, although this would demand even more labors from the CFMGs, which is already a key limitation. Financial support for fencing materials and labor could not only help CFMGs but also would encourage them to put more effort into managing their plantations for improved timber production.

\subsection{Ecosystem Services}

The CFMG members at both sites identified a suite of 11 ecosystem services derived from the planted forest areas (Tables 2 and 3). Provisioning services included wild edibles such as fern 
fiddleheads and mushrooms, cypress greens for religious use, and leaf litter, and fodder for animals and fertilizer. No harvest of timber had been conducted since planting at any site since the trees had not yet reached commercial size, though some flag poles had been harvested in some sites.

Table 2. Description of ecosystem services from the planted forests in Punakha and Trashigang dzongkhags.

\begin{tabular}{|c|c|c|}
\hline Ecosystem Category & Ecosystem Identified & Description \\
\hline \multirow[t]{5}{*}{ Provisioning services } & Timber & $\begin{array}{l}\text { Timber for construction and renovation is the } \\
\text { primary resource expected to be gained from } \\
\text { the planted forest. }\end{array}$ \\
\hline & Leaf litter & $\begin{array}{l}\text { Leaf litter is collected for animal bedding, } \\
\text { which will be transferred to agricultural land } \\
\text { as manure. }\end{array}$ \\
\hline & Fodder & $\begin{array}{l}\text { Fodder (live leaves and small branches) is } \\
\text { collected by farmers or animals browse } \\
\text { directly in the forest. }\end{array}$ \\
\hline & Incense & $\begin{array}{l}\text { Fresh leaves from the cypress trees are } \\
\text { harvested and used as incense during } \\
\text { everyday worship and the annual festivals. } \\
\text { Source of income. }\end{array}$ \\
\hline & * NWFP edibles & $\begin{array}{l}\text { Mushrooms and fern fiddleheads are } \\
\text { collected for household use or sale. } \\
\text { Source of income. }\end{array}$ \\
\hline \multirow[t]{2}{*}{ Regulating services } & Water resource & $\begin{array}{l}\text { Stream water is collected for drinking, } \\
\text { domestic use and irrigation. }\end{array}$ \\
\hline & Water regulation & $\begin{array}{l}\text { Restored landscape protects soil from erosion } \\
\text { and landslide }\end{array}$ \\
\hline \multirow[t]{2}{*}{$\begin{array}{l}\text { Cultural and amenity } \\
\text { services }\end{array}$} & Aesthetic landscape & $\begin{array}{l}\text { The landscape looks beautiful after the barren } \\
\text { land is planted with trees, provides a pleasant } \\
\text { place for people to be. }\end{array}$ \\
\hline & Education/learning & $\begin{array}{l}\text { After the barren land is forested, students } \\
\text { from the nearby schools comes for study and } \\
\text { leisure. Source of income. }\end{array}$ \\
\hline \multirow[t]{2}{*}{ Supporting services } & Wildlife habitat & Forest area provides habitat for wildlife. \\
\hline & Plant diversity & $\begin{array}{l}\text { Forest restoration facilitates the establishment } \\
\text { of other plant species, increasing the diversity } \\
\text { of the habitat for wildlife. }\end{array}$ \\
\hline
\end{tabular}

* Non-Wood Forest Products (NWFP).

On the regulating services, improved vegetation cover and protection of soil erosion were the two services mentioned most prominently in Punakha, and water provision was highly ranked in Khaling. In Punakha, while only three members interviewed at one site indicated that protecting the water source was an objective of the reforestation effort, all members indicated that water quality had improved. Water was not mentioned in any of the interviews from the other sites in Punakha, but it featured strongly in Khaling (Table 3). The planted area serves as improved habitat for wild animals, yet there were concerns about these animals debarking the trees. 
Table 3. Ecosystem services from community plantations identified by CFMGs in Punakha and Trashigang dzongkhags.

\begin{tabular}{|c|c|c|c|c|c|c|}
\hline \multirow{2}{*}{ Ecosystem Services } & \multicolumn{6}{|c|}{ Community Forest } \\
\hline & Kuenphen & Mangizingkha & Phentog & Thuenkey & Yargey & Khaling \\
\hline \multicolumn{7}{|l|}{ Provisioning services } \\
\hline Flag pole & $\checkmark$ & $\checkmark$ & & & & \\
\hline Leaf litter & $\checkmark$ & & & & $\checkmark$ & $\checkmark$ \\
\hline Fodder & & & $\checkmark$ & & & \\
\hline Incense & & & $\checkmark$ & & $\checkmark \checkmark$ & $\checkmark$ \\
\hline NWFP edibles & & & $\checkmark$ & $\checkmark$ & & \\
\hline \multicolumn{7}{|l|}{ Regulating services } \\
\hline Water/soil regulation & $\checkmark$ & $\checkmark$ & & $\checkmark$ & $\checkmark$ & $\checkmark$ \\
\hline Water resources & & & & & & $\checkmark$ \\
\hline \multicolumn{7}{|l|}{ Cultural and amenity } \\
\hline Aesthetic, sport & $\checkmark$ & & & & $\checkmark \checkmark$ & $\checkmark$ \\
\hline Education & & $\checkmark$ & & & & $\checkmark$ \\
\hline \multicolumn{7}{|l|}{ Supporting services } \\
\hline Wildlife habitat & $\checkmark$ & $\checkmark$ & & $\checkmark$ & $\checkmark$ & \\
\hline $\begin{array}{c}\text { Increased plant } \\
\text { diversity }\end{array}$ & $\checkmark$ & $\checkmark$ & $\checkmark$ & & $\checkmark$ & \\
\hline
\end{tabular}

A ranking exercise carried out in the three focus group discussions in Khaling to identify the most important services revealed differences among villages, which were to some degree depending on the proximity of the village to the planted forest (Table 4). For regulating services, the villagers closest to the forest plantation (Rashong village) placed drinking water as the service with the highest priority. Of the three villages, Rashong is the only village that harvests water from a stream that comes from nearby planted forest. They perceived that the quantity and the quality of the water has increased and improved due to decreased sedimentation. Although the water was not important for other two villages, they were of the opinion that the water quality and quantity have improved. They cited that today there is ample supply of water to the government institutions based at Khaling and the small village town, which otherwise was not the case before the restoration of this degraded hillside. They perceived that sedimentation and flash flooding have drastically decreased in the area where the present planted forest is located.

Table 4. Ecosystem ranking by three villages of Khaling community in Trashigang dzongkhag *.

\begin{tabular}{ccccc}
\hline & & & \multicolumn{2}{c}{ Villages } \\
\hline Ecosystem Service Category & Ecosystem Service & Bremeng-Dangrey-Kholdong & Dawzor & Rashong \\
\hline Provisioning services & Animal bedding & Sixth & Sixth & Fifth \\
& Incense & First & Third & Third \\
Regulating services & Fresh Water & Second & Fourth & First \\
& Water regulation & Third & First & Second \\
Cultural and amenity services & Aesthetic landscape & Fourth & Second & Fourth \\
& Education/learning & Fifth & Fifth & Sixth \\
\hline
\end{tabular}

${ }^{*}$ Note: timber is excluded because it is the highest priority for the future, but not yet mature.

Dawzor, the second farthest village from the planted forest, also ranked water from the nearby planted forest as their first priority. This village does not draw water from this particular water source, 
though they benefit indirectly, claiming that when their neighboring village and the people from the government institutions have enough water, their own water source need not be shared. Improved aesthetic was ranked second in Dawzor.

Under provisioning service, the participants from the farthest village (Bremeng-DangreyKholdong) ranked incense as the topmost priority. They have a small temple within the village where incense is burnt every day. They also hold an annual religious festival where the use of incense is important and extensive. They feel that the distance for collection of incense has drastically reduced since the trees were planted and has eased their collection efforts.

Negative impacts of the planted forests were also mentioned in the FGDs. Crows roosting in the forest now eat the spouting maize seeds and mammals now destroy crops. People were likewise aware of the negative impact of animal husbandry on the local forest, as they mentioned that the grazing of cattle in the forest suppresses the regeneration of seedlings, jeopardizing the future of the forest.

\section{Discussion}

The study reveals 11 key ecosystem services provided by community planted forests that are recognized and utilized by neighboring communities. Using social survey methods, including interviews and focus group discussions, we found that communities perceived and prioritized different forest ecosystem values according to their needs and proximity of their village to the planted forest. Identification and the high prioritization of timber and non-timber forest resources from these planted forests reveals a distinct reliance on and appreciation for local forest resources by rural villagers.

In eastern Bhutan, where land degradation is more prevalent and water is more scarce, water regulation services are perceived as the most important of the community forest plantation, followed by the provision of water resources. All three villages in the Trashigang site agreed well with each other that downstream flooding had been reduced after the establishment of the forest plantation, which they consider to be a major achievement. This finding is consistent with the results of a similar study of oak forests in Bhutan, where water provisioning services of the forest was ranked highest across the country [44] and elsewhere in the region [45]. Studies show that water quality improves through increased uptake of nutrient and non-nutrient chemicals by the root systems of the vegetation [46]. This should be verified empirically in the field, since scientific evidence shows that, in some places, increasing forest cover results in less ground and surface water due to evapotranspiration [47].

Past studies on forest resource management have focused mainly on biophysical and economic valuation [48], giving little attention to social values [49-51]. There is also ongoing debate about the positive and negative impacts of planted forests on multiple ecosystem services. While many authors claim planted forests can help mitigating climate change [43,52], support biodiversity [17], and take economic pressure off from native forests [53], others contradict these claims overall, suggesting that rather than benefiting the environment, planting trees do more harm than good [54]. Our study was designed to contribute to this emerging discussion.

In the past decade, work on assessing and valuing ecosystem services has been increasing rapidly [55]. This study confirms that the communities that have helped to establish restored forest through the community plantation program have benefited from the ecosystem services of the new forest. In general, the perceptions by villagers of the value of the planted forest ecosystem to local communities was significant but lower in comparison to natural forests in Bhutan [38,44], which has been found elsewhere [56]. This may be attributed to the fact that the planted areas under study were small and young.

The original problems that led to the forest restoration in these areas, including soil erosion and shortage of wood resources, seem to be at least partially mitigated by the community plantation efforts and subsequent regularization of the planted forest into the larger community forest area. Our study confirms that local people perceive that the new forests have reduced soil erosion, improved water quantity and quality, resulted in aesthetic improvements, and will bring income to the CFMGs in the near future. Future research could attempt to test these perceptions as hypotheses through field 
measurements. Reforestation has also brought human-wildlife interaction in the study areas, which is perceived by the local community as a negative impact, or dis-service, of forest expansion, as found elsewhere [57]. In many parts of the world, large scale, intensively managed timber plantations have mixed socio-economic and environmental outcomes [13]. Community knowledge of their perceived impacts is important for better management and integration of plantations into the rural landscape [58].

As elsewhere in Bhutan [44], and unlike other locations such as Brazil and Uruguay [15,59], participants of our study in perceived that the water supply had increased in quantity after the installation of the planted forest. This supports the idea of establishing a payment for the ecosystem service scheme that links water service delivery to the town of Khaling with the community forest area, as there is precedent for this type of scheme in other areas of Bhutan and around the world [60]. While it is difficult to accurately estimate the amount of water consumed by vegetation, it is generally agreed that, for moderate rainfall events, a forest will capture and emit more water than grassland and annual crops [61]. Rainfall events that exceed a certain intensity, however, will not be fully mitigated by the presence of any sort of vegetation. This may be due to the small scale of plantations which are distributed across the landscape in Bhutan rather than large scale plantations in Brazil and Uruguay.

An unexpected outcome of the reforestation initiative in Khaling was the resolution of land use conflict between migratory herders and year-round residents. Prior to the reforestation of this hillside, the open areas was used seasonally by herders from neighboring geogs of Merak and Sakteng, where migratory herds are present. Land use conflicts were observed during the establishment phase of the plantation, as the grazing animals damaged the seedlings or villagers tried to keep them out. The creation of the forest plantation became part of a strategy that included laws, fines and patrolling to eventually keep the herds away from the locality. To ease the degree of conflict, tree planting was conducted in a series of waves (patch wise) to allow the herders continued access to unplanted areas until ultimately the corridor was completed in 2007. Once the whole area came under forest plantation, the herders stopped bringing their cattle and the issue of land use conflict and water pollution faded away. Also in Khaling, villagers suggested that improved water quantity to the main town after reforestation alleviated conflicts over the use of village water.

Although the planted forests in this study were established as monoculture with cypress, efforts were made to diversity the tree component with the additional planting of cyptomeria and oak. Forest floor species such as fungi and ferns occurred spontaneously and were appreciated for their nutritional, cultural and/or income value. Cypress performed well at most sites, but management was limited, which might have retarded growth. Care should be taken in the future to plant species appropriate to the site and to conduct management activities in accordance with the multiple goals [62].

\section{Conclusions}

With sound policy and strong laws in place, the Bhutanese population continues to enjoy and cherish its pristine forested environment and benefit from the conservation of its natural resources. While this mountainous nation enjoys 72 percent forest cover, there are key areas where deforestation and land degradation have led to soil erosion, local flooding and landslides. As a response, and throughout history, the government and Bhutanese people have conducted reforestation activities to return forest vegetation to degraded, barren, and over-harvested areas.

It appears that the long-standing commitment of the Royal Government of Bhutan to care for and restore forests in this mountainous country is successful. While records suggest that formal forest planting was occurring as early as 1947, the commitment was cemented in the nation's constitution and reiterated in the most recent forest policy.

Although the study gives new insights on ecosystem services from planted forests in Bhutan, it has some limitations to be considered for future research. First, the assessment was in only six of several dozen planted forest areas in Bhutan. Assessing the process and outcomes of reforestation at different locations, with other species and under different forest tenure regimes, could reveal distinct environmental service provisions. Second, this study stopped short of verifying and quantifying the 
perceptions and claims by villagers of the ecosystem services from these forests. Finally, while we used a participatory research methodology designed to result in a two-way flow of information, we did not assess the impact of participation in the knowledge of participants about their forest and the concepts related to ecosystem services.

Assessments of the perceptions of ecosystem services from planted forests can be replicated in other forest management areas, including private and state owned forest. Local knowledge and community values are essential components in natural resource management programs [52], while at the same time, truly erroneous beliefs that might lead to poor management decisions can be gently yet convincingly debunked for local populations.

The study could be a lesson learnt for other countries to consider the benefits community-based forest restoration planting. We believe that supporting communities and small-scale landholders to restore forest on degraded sites is an effective approach for nations to meet their commitments made under the various multilateral environmental agreements, such as the Bonn Challenge on forest restoration, the New York Declaration on Forests Goal 5 to restore forests and targets under the SDG 15, and the UN Decade of Ecosystem Restoration.

Author Contributions: Conceptualization, P.B.R.; D.D.; R.R.S.; S.P. and H.B.; methodology, P.B.R.; R.R.S. and S.P.; software, P.B.R.; validation, P.B.R.; D.D. and R.R.S.; formal analysis, P.B.R.; investigation, P.B.R. and D.D.; resources, H.B.; data curation, P.B.R. and D.D.; writing-original draft preparation, P.B.R.; writing-review and editing, R.R.S.; Y.A. and H.B.; visualization, P.B.R.; supervision, D.D. and H.B.; project administration, D.D.; S.P. and Y.A.; funding acquisition, D.D.; R.R.S.; Y.A. and H.B. All authors have read and agreed to the published version of the manuscript.

Funding: This research was funded by the Republic of Austria.

Acknowledgments: This research was carried out jointly by the Ugyen Wangchuck Institute for Conservation and Environmental Research (UWICER) and the Center for International Forestry Research (CIFOR) as part of the CGIAR Research Program on Forests, Trees and Agroforestry. This project is a component of CIFOR's Sloping Land in Transition (SLANT) research program. The authors gratefully acknowledge the generosity of the villagers who participated in the research activities, the public servants who served as survey enumerators and meeting facilitators and to UWICER colleagues Kinley Choden and Jigme Wangchuk for project support.

Conflicts of Interest: The authors declare no conflict of interest.

\section{References}

1. FAO and UNEP. The State of the World's Forests 2020. Forests, Biodiversity and People; Food and Agriculture Organization of the United Nations and The United Nationd of Environment Programme: Rome, Italy, 2020.

2. FAO. Global Forest Resource Assessment 2020. Terms and Definitions; Food and Agriculture Organization of the United Nations: Rome, Italy, 2018.

3. Payn, T.; Carnus, J.M.; Freer-Smith, P.; Kimberley, M.; Koller, W.; Liu, S.; Orazio, C.; Rodrigue, L.; Silva, L.N.; Wingfield, M.J. Changes in planted forests and future global implications. For. Ecol. Manag. 2015, 352, 57-67. [CrossRef]

4. Lamb, D. Regreening the Bare Hills: Tropical Forest Restoration in the Asia-Pacific Region; Springer: Dordrecht, The Netherlands, 2010.

5. Chazdon, R.L. Beyond deforestation: Restoring forests and ecosystem services on degraded lands. Science 2008, 320, 1458-1460. [CrossRef]

6. Chokkalingam, U.; Sabogal, C.; Almeida, E.; Carandang, A.P.; Gumartini, T.; de Jong, W.; Brienza, S., Jr.; Lopez, A.M.; Nawir, A.A.; Rumboko, L.; et al. Local participation, livelihood needs, and institutional arrangements: Three keys to sustainable rehabilitation of degraded tropical forest lands. In Forest Restoration in Landscapes; Mansourian, S., Vallauri, D., Dudley, N., Eds.; Springer: New York, NY, USA, 2005; pp. 405-414.

7. Paquette, A.; Messier, C. The role of plantations in managing the world's forests in the Anthropocene. Front. Ecol. Environ. 2009, 8, 27-34. [CrossRef]

8. Matthews, S.; O'Connor, R.; Plantinga, A.J. Quantifying the impacts on biodiversity of policies for carbon sequestration in forests. Ecol. Econ. 2002, 40, 71-87. [CrossRef] 
9. Makino, S.I.; Goto, H.; Hasegawa, H.; Okabe, I.; Tanaka, H.; Inoue, T.; Okochi, I. Degradation of longicorn beetle (Coleoptera, Cerambycidae, Disteniidae) fauna caused by conversion from broad-leaved to man-made conifer stands of Cryptomeria japonica (Taxodiaceae) in central Japan. In Sustainability and Diversity of Forest Ecosystems; Nakashizuka, T., Ed.; Springer: Tokyo, Japan, 2007; pp. 372-381.

10. Lewis, S.L.; Wheeler, C.E.; Mitchard, E.T.A.; Koch, A. Restoring natural forest is the best way to remove atmospheric carbon. Nature 2019, 568, 25-28. [CrossRef] [PubMed]

11. Carnus, J.M.; Parrotta, J.; Brockerhoff, E.; Arbez, M.; Jactel, H.; Kremer, A.; Lamb, D.; O’Hara, K.; Walters, B. Planted forests and biodiversity. J. For. 2006, 104, 65-77.

12. Brockerhoff, E.G.; Jactel, H.; Parrotta, J.A.; Quine, C.P.; Sayer, J. Plantation forests and biodiversity: Oxymoron or opportunity? Biodivers. Conserv. 2008, 17, 925-951. [CrossRef]

13. Pirard, R.; Petit, H.; Baral, H. Local impacts of industrial tree plantations: An empirical analysis in Indonesia across plantation types. Land Use Policy 2017, 60, 242-253. [CrossRef]

14. Malkamäki, A.; D'Amato, D.; Hogarth, N.J.; Kanninen, M.; Pirard, R.; Toppinen, A.; Zhou, W. A systematic review of the socio-economic impacts of large-scale tree plantations, worldwide. Glob. Environ. Chang. 2018, 53, 90-103. [CrossRef]

15. Switzer, M.B. Planting progress? The everyday impacts of plantation forestry on small farmers in interior Uruguay. Environ. Justice 2014, 7, 77-80. [CrossRef]

16. Gutiérrez Rodríguez, L.; Hogarth, N.J.; Zhou, W.; Xie, C.; Zhang, K.; Putzel, K. China's conversion of cropland to forest program: A systematic review of the environmental and socioeconomic effects. Environ. Evid. 2016, 5, 21. [CrossRef]

17. Baral, H.; Guariguata, M.; Keenan, R.J. Proposed framework for assessing ecosystem services from planted forests. Ecosyst. Serv. 2016, 22B, 260-268. [CrossRef]

18. Lamb, D. Undertaking large-scale forest restoration to generate ecosystem services. Restor. Ecol. 2018, 4, 657-666. [CrossRef]

19. Lamb, D. Large-Scale Forest Restoration; Routledge: New York, NY, USA, 2014.

20. Foley, J.A.; DeFries, R.; Asner, G.P.; Barford, C.; Bonan, G.; Carpenter, S.R.; Chapin, F.S.; Coe, M.T.; Daily, G.C.; Gibbs, H.K.; et al. Global consequences of land use. Science 2005, 309, 570-574. [CrossRef]

21. Lambin, E.F.; Meyfroidt, P. Land use transitions: Socio-ecological feedback versus socio-economic change. Land Use Policy 2010, 27, 108-118. [CrossRef]

22. Fremier, A.K.; DeClerck, F.A.; Bosque-Pérez, N.A.; Carmona, N.E.; Hill, R.; Joyal, T.; Keesecker, L.; Klos, P.Z.; Martínez-Salinas, A.; Niemeyer, R.; et al. Understanding spatiotemporal lags in ecosystem services to improve incentives. BioScience 2013, 63, 472-482. [CrossRef]

23. Viviroli, D.; Weingartner, R.; Messerli, B. Assessing the hydrological significance of the world's mountains. Mt. Res. Dev. 2003, 23, 32-40. [CrossRef]

24. Sears, R.R.; Choden, K.; Dorji, T.; Dukpa, D.; Phuntsho, S.; Rai, P.B.; Wangchuk, J.; Baral, H. Bhutan's forests through the framework of ecosystem services: Rapid assessment in three forest types. Forests 2018, 9, 675. [CrossRef]

25. Putzel, L.; Baral, H.; Zhang, K.; Artati, Y.; Cronkleton, P. Studies on forest landscape restoration in hilly and mountainous regions of Asia and Africa-An introduction to the Special Issue. Int. For. Rev. 2017, 19, 1-7. [CrossRef]

26. Dorji, L.; Webb, E.L.; Shivakoti, G.P. Forest property rights under nationalized forest management in Bhutan. Environ. Conserv. 2006, 33, 141-147. [CrossRef]

27. Phuntsho, S.; Schmidt, K.; Kuyakanon, R.S.; Temphel, K.J. Community Forestry in Bhutan: Putting People at the Heart of Poverty Reduction; Ugyen Wangchuck Institute for Conservation and Environment and Social Forestry Division: Jakar and Thimphu, Bhutan, 2011.

28. MAF (Ministry of Agriculture and Forests). Forest and Nature Conservation Rules and Regulations of Bhutan; Royal Government of Bhutan: Thimphu, Bhutan, 2017.

29. Penjore, D.; Rapten, P. Trends of forestry policy concerning local participation in Bhutan. In Policy Trend Report; Harada, K., Nanang, M., Eds.; Institute for Global Environmental Strategies: Kanagawa, Japan, 2004; pp. 21-27.

30. Temphel, K.J.; Beukeboom, H.J. Community forestry in Bhutan contributes to poverty reduction while maintaining the sustainability of the resources. In Proceedings of the International Conference on Poverty Reduction and Forests Tenure, Market and Policy Reforms, Bangkok, Thailand, 3-7 September 2007; pp. 3-7. 
31. DoFPS. Forest Facts and Figures 2017; Department of Forests and Park Services, Ministry of Agriculture and Forests, Royal Government of Bhutan: Thimphu, Bhutan, 2018.

32. Dorji, R.; Schmidt, K. Review of community forestry and analysis of its strengths and weaknesses for future directions. In Participatory Forest Management Project, Phase III; Department of Forests and Park Services, Ministry of Agriculture and Forests, Royal Government of Bhutan, HELVETAS: Thimphu, Bhutan, 2014.

33. Rahut, D.B.; Ali, A.; Behera, B. Household participation and effects of community forest management on income and poverty levels: Empirical evidence from Bhutan. For. Policy Econ. 2015, 61, 20-29. [CrossRef]

34. Norbu, L.; Dhital, D.B.; Wangda, P. Reforestation in Bhutan: Accomplishments and prospects. Keep Asia Green 2008, 3, 67-109.

35. Social Forestry Division. National Strategy for Community Forestry: The Way Forward, Department of Forests and Park Services; Ministry of Agriculture and Forests: Thimphu, Bhutan, 2010.

36. Buffum, B.; Lawrence, A.; Temphel, K.J. Equity in community forests in Bhutan. Int. For. Rev. 2010, 12, 187-199. [CrossRef]

37. Tshering, K.; Dema, K.; Tshering, D.; Dorji, P.; Officer, F. Assessment of forest ecosystem services in Khaling Gewog, Bhutan. J. Agrofor. Environ. 2012, 6, 41-44.

38. Kandel, P.; Tshering, D.; Uddin, K.; Lhamtshok, T.; Aryal, K.; Karki, S.; Sharma, B.; Chettri, N. Understanding social-Ecological interdependence using ecosystem services perspective in Bhutan, Eastern Himalayas. Ecosphere 2018, 9, e02121. [CrossRef]

39. Ohsawa, M. (Ed.) Life Zone Ecology of the Bhutan Himalaya; Laboratory of Ecology, Chiba University: Chiba, Japan, 1987.

40. MoAF. Atlas of Bhutan: Land Use Land Cover 2016, Statistics; Forest Resources Management Division, Department of Forests \& Park Services, Ministry of Agriculture and Forests: Thimphu, Bhutan, 2017.

41. Wangdue Divisional Forest Office. Data Community Forest; Punakha, Bhutan, Unpublished work; 2016.

42. Paudyal, K.; Adhikari, S.; Sharma, S.; Samsudin, Y.B.; Paudyal, B.R.; Bhandari, A.; Birhane, E.; Darcha, G.; Trinh, T.L.; Baral, H. Framework for Assessing Ecosystem Services from Bamboo Forests: Lessons from Asia and Africa; Working Paper 255; Center for International Forestry Research: Bogor, Indonesia, 2019.

43. Paudyal, K.; Samsudin, Y.B.; Baral, H.; Okarda, B.; Phuong, V.T.; Paudel, S.; Keenan, R.J. Spatial assessment of ecosystem services from planted forests in central Vietnam. Forests 2020, 11, 822. [CrossRef]

44. Dorji, T.; Brookes, J.D.; Facelli, J.M.; Sears, R.R.; Norbu, T.; Dorji, K.; Chhetri, Y.R.; Baral, H. Socio-cultural values of ecosystem services from Oak Forests in the Eastern Himalaya. Sustainability 2019, 11, 2250. [CrossRef]

45. Paudyal, K.; Baral, H.; Keenan, R.J. Assessing social values of ecosystem services in the Phewa Lake Watershed, Nepal. For. Policy Econ. 2018, 90, 67-81. [CrossRef]

46. Dosskey, M.G.; Vidon, P.; Gurwick, N.P.; Allan, C.J.; Duval, T.P.; Lowrance, R. The role of riparian vegetation in protecting and improving chemical water quality in streams 1. JAWRA J. Am. Water Resour. Assoc. 2010, 46, 261-277. [CrossRef]

47. Tan, Z.H.; Zhang, Y.P.; Song, Q.H.; Liu, W.J.; Deng, X.B.; Tang, J.W.; Deng, Y.; Zhou, W.J.; Yang, L.Y.; Yu, G.R.; et al. Rubber plantations act as water pumps in tropical China. Geophys. Res. Lett. 2011, 38, 24. [CrossRef]

48. Schröter, M.; van der Zanden, E.H.; van Oudenhoven, A.P.; Remme, R.P.; Serna-Chavez, H.M.; de Groot, R.S.; Opdam, P. Ecosystem services as a contested concept: A synthesis of critique and counter-arguments. Conserv. Lett. 2014, 7, 514-523. [CrossRef]

49. Smith, H.F.; Sullivan, C.A. Ecosystem services within agricultural landscapes: Farmers' perceptions. Ecol. Econ. 2014, 98, 72-80. [CrossRef]

50. Cole, Z.; Holland, S.; Donohoe, H. A social values typology for comprehensive assessment of coastal zone ecosystem services. Soc. Nat. Resour. 2015, 28, 1290-1307. [CrossRef]

51. van Riper, C.J.; Kyle, G.T.; Sherrouse, B.C.; Bagstad, K.J.; Sutton, S.G. Toward an integrated understanding of perceived biodiversity values and environmental conditions in a national park. Ecol. Indic. 2017, 72, 278-287. [CrossRef]

52. Bastin, J.F.; Finegold, Y.; Garcia, C.; Mollicone, D.; Rezende, M.; Routh, D.; Zohner, C.M.; Crowther, T.W. The global tree restoration potential. Science 2019, 365, 76-79. [CrossRef]

53. Ghazoul, J.; Bugalho, M.; Keenan, R. Plantations take economic pressure off natural forests. Nature 2019, 570, 307-308. [CrossRef] [PubMed] 
54. Heilmayr, R.; Echeverría, C.; Lambin, E.F. Impacts of Chilean forest subsidies on forest cover, carbon and biodiversity. Nat. Sustain. 2020, 22,1-9. [CrossRef]

55. Braat, L.C.; De Groot, R. The ecosystem services agenda: Bridging the worlds of natural science and economics, conservation and development, and public and private policy. Ecosyst. Serv. 2012, 1, 4-15. [CrossRef]

56. Carnol, M.; Baeten, L.; Branquart, E.; Grégoire, J.C.; Heughebaert, A.; Muys, B.; Ponette, Q.; Verheyen, K. Ecosystem services of mixed species forest stands and monocultures: Comparing practitioners' and scientists' perceptions with formal scientific knowledge. Forestry 2014, 87, 639-653. [CrossRef]

57. Shrestha, U.B.; Shrestha, B.B.; Shrestha, S. Biodiversity conservation in community forests of Nepal: Rhetoric and reality. Int. J. Biodivers. Conserv. 2010, 2, 98-104.

58. Pirard, R.; Petit, H.; Baral, H.; Achdiawan, R. Perceptions of local people toward pulpwood plantations: Insights from the Q-method in Indonesia. Int. For. Rev. 2016, 18, 218-230. [CrossRef]

59. Garcia, L.G.; Salemi, L.F.; de Paula Lima, W.; de Barros Ferraz, S.F. Hydrological effects of forest plantation clear-cut on water availability: Consequences for downstream water users. J. Hydrol. 2018, 19, 17-24. [CrossRef]

60. Jenkins, M.; Salzman, J.; Bennett, G.; Granfors, J. Making the priceless valuable: Forests and ecosystem services. Int. For. Rev. 2020, 22, 104-112.

61. Zhang, L.; Dawes, W.R.; Walker, G.R. Response of mean annual evapotranspiration to vegetation changes at catchment scale. Water Resour. Res. 2001, 37, 701-708. [CrossRef]

62. Langenberger, G.; Liu, J. Performance of smallholder teak plantations (Tectona grandis) in Xishuangbanna, south-west China. J. Trop. For. Sci. 2013, 1, 289-298.

(C) 2020 by the authors. Licensee MDPI, Basel, Switzerland. This article is an open access article distributed under the terms and conditions of the Creative Commons Attribution (CC BY) license (http://creativecommons.org/licenses/by/4.0/). 